\title{
DJE\&E \\ Measuring the Environmental Impact of Power Generation at GSM Base Station Sites
}

\author{
Ani Vincent Anayochukwu ${ }^{1 *}$ Emetu Alice Nnene ${ }^{2}$ \\ ' Department of Electronic Engineering, University of Nigeria, Nsukka, Nigeria. \\ ${ }^{2}$ Department of Nutrition and Dietetics, University of Nigeria, Nsukka, Nigeria. \\ * Corresponding author: Email: vincent_ani@yahoo.com. Phone Number: \\ +2348054024629 .
}

ABSTRACT There is a need to quantify the environmental impact of powering macro base transmitter station sites with diesel generators. The energy consumption of diesel generators to power base stations for telecommunication networks is a contributor to global greenhouse gas (GHG) emissions. This paper presents a model for calculating emission generation. The model was used to study the environmental impact of macro radio base stations powered by diesel generators using the Hybrid Optimization Model for Electric Renewables (HOMER) - optimization and simulation software tool. The environmental impact of powering base stations with diesel generators was assessed by quantifying the emissions generated in terms of pollution and the impact in terms of environmental cost $(\$ 200 t / y r)$. From the results of emissions generated from diesel generators and presented in this study [105.96 tonnes of carbon dioxide $\left(\mathrm{CO}_{2}\right), 0.26$ tonnes of carbon monoxide (CO), 0.03 tonnes of unburned hydrocarbons (UHC), 0.02 tonnes of particulate matter (PM), 0.21 tonnes of sulfur dioxide $\left(\mathrm{SO}_{2}\right)$, and 2.33 tonnes of nitrogen oxides $\left(\mathrm{NO}_{\mathrm{X}}\right)$ ], the use of diesel generators to power GSM base station sites is concluded to have significant environmental impact.
Received 09 January 2013; revision received 16 February 2013; accepted 18 February 2013. Published online 30 April 2013 (www.ejee.cl). DOI:10.7770/ejee-V1N1-art479.

○) Renewable Energies Research Nucleus, UC Temuco.

KEYWORDS Pollutant emission, environmental pollutions, diesel generator, simulation, macro base transmitter station, Nigeria.

\section{Introduction}

Currently, the industrial sector continues to increase GHG emissions through the use of fossil fuels in heavy-duty electricity generators. This practice is especially evident since the year 2001, with the arrival of the global system of mobile telecommunication (GSM) in Nigeria. Due to the large patronage from millions of subscribers and potential users, GSM operators persist in extending their network coverage across the country. Today, there are about 20 different GSM companies operating within Nigeria. On the University of Nigeria Nsukka Campus alone, about 7 base stations belonging to 3 different telecommunications companies are present, while more are being proposed. Incidentally, these base station sites are continually powered by diesel engine generators round the clock. In Nigeria, at the time of this investigation, diesel generators are commonly used to power these sites. This is mainly due to limited avai- 
lability of the national electricity grid, and therefore the task of providing uninterrupted power to satisfy minimum quality of service (QoS) requirements is difficult. Presently, all the base station sites on campus are deployed with diesel generators as their primary source of electrical power. These generators are powered by fossil fuels (diesel) which contributes to the emission of atmospheric pollutants such as $\mathrm{CO}_{2}$, $\mathrm{CO}, \mathrm{PM}, \mathrm{SO}_{2}$, and $\mathrm{NO}_{\mathrm{X}}$, which are proven harmful to bio-organisms.

Power generation at GSM base stations in $\mathrm{Ni}$ geria is considered as an emerging source of GHG emissions and metropolitan atmospheric pollution [Adeofun et al., 2009]. Electricity production is often a source of $\mathrm{CO}_{2}$ emissions, such as when fossil fuel is combusted in power plants. In view of this, the energy production for base station sites is the main polluting factor from the telecommunications industry. The ability to use mobile phones at any time means that the network must be powered at all times. However, the environmental impact of any constant human activity in nature should be closely scrutinized [Ani, 2012]. Accumulations of GHGs within living areas could have chronic toxic effects, especially at concentrations above permissible limits. The health safety standard for emission of CO into the environment over a period of 8 hours is 9 ppm and $35 \mathrm{ppm}$ over 1 hour, and that of $\mathrm{NO}_{\mathrm{X}}$ in the environment over a year period is $0.005 \mathrm{ppm}$, while that of $\mathrm{SO}_{2}$ in the environment within 24 hours is only $0.14 \mathrm{ppm}$ and $0.003 \mathrm{ppm}$ in one year. [USEPA AIRS database, 2008; Air Quality Technical Report, 2008; Federal Ministry of Environment, 1991].

In Nigeria, the location in which GSM sites are built remains largely unregulated in practice. Clearly a governing entity is in order to enforce the existing regulations regarding the location of these sites. Most of these base stations are in close proximity with human living quarters and even clustered on school grounds. The environmental impact of these sites is not considered, in terms of pollution from the diesel generators used to power these stations. Consequently, GHG emissions steadily increase, as well as the generation of various other environmental pollu- tants. Given the rise and rapid growth of these sites, quantification of the environmental impact of powering GSM base station sites with diesel generators is necessary.

The purpose of this study is to assess the environmental impact of powering base stations with diesel generators and to examine the effect of the operational hours of diesel generators on the emission of pollutants.

\section{Energy consumption at a macro base transceiver station site}

A base transceiver station (BTS) is a tower or mast mounted with telecommunications equipment (e.g. antenna, radio receiver and transmitters) that enables the transmission of mobile signals (voice and data). At the bottom of each tower, there is a shelter with additional transmission equipment, air conditioning, battery racks and - for those that are off-grid or with unreliable electricity supply - in a separate room, the diesel generator [Ani, 2013]. The energy consumption of the various components at a typical BTS site has been categorized by [Pierre, 2006; Roy, 2008; Willson, 2009; GSMA, 2009; Ani and Nzeako, 2012] as follows:

\section{Radio equipment:}

- Radio unit [Radio Frequency (RF) Conversion and Power Amplification] $=4160 \mathrm{~W}$

- Base band [Signal Processing and Control] = $2190 \mathrm{~W}$

\section{Power conversion equipment:}

- Power Supply and Rectifier $=1170 \mathrm{~W}$

3. Antenna equipment

- $\mathrm{RF}$ feeder $=120 \mathrm{~W}$

- Remote monitoring and safety (aircraft warning light $)=100 \mathrm{~W}$

\section{Transmission equipment}

- Signal transmitting $=120 \mathrm{~W}$

5. Climate equipment

- Air conditioning $=2590 \mathrm{~W}$

6. Auxiliary equipment

- Security and lighting $=200 \mathrm{~W}$ 


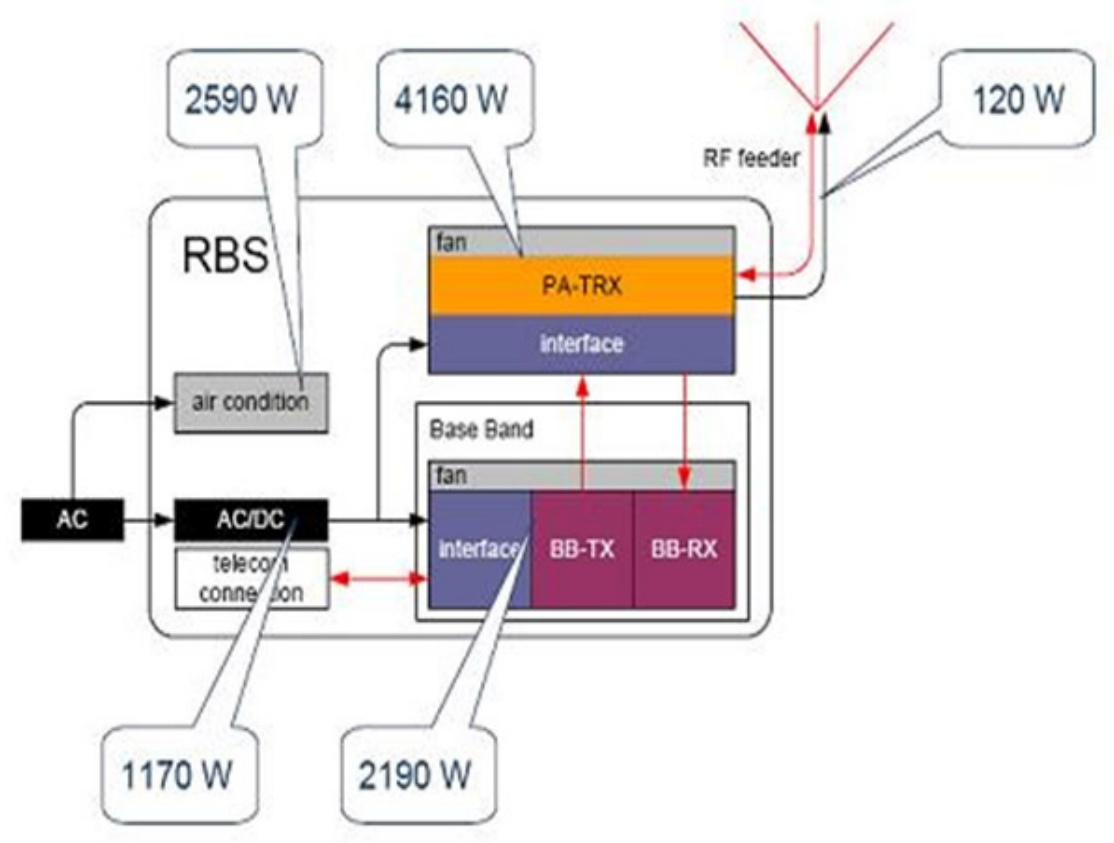

Figure 1 Power consumption of radio base station [Pierre, 2006].

According to this model, a site consumes 10.7 kWh of electricity.

\section{Environmental impact}

The environmental impact of diesel fuel combustion is quite serious, and it is local and global. According to the California Air Resources Board, "Diesel engines release a host of harmful substances, including directly emitted organic and elemental carbon (soot), toxic metals, nitrogen oxides that form ozone and nitrate particulate matter, volatile organic compounds, carbon monoxide, carbon dioxide, and a variety of toxic metals and gases such as formaldehyde, acrolein, and polycyclic aromatic hydrocarbons" [California Air Resources Board, 2000]. This means serious impacts for the environment beyond direct health concerns for humans, but also for the air, water and soil. Black carbon particles, sulfur oxides and heavy metals in diesel exhaust also present numerous issues of soil contamination. Black carbon arrives to the topsoil through precipitation and affects the ability of plants to extract nutrients from the soil, as well as affecting the soil's ability to absorb and hold water [Ghosh, 2007]. This can have an impact on the ability to cultivate staple crops used as a food-source and for the production of alternative fuels. In addition, the other toxins found in diesel exhaust will be deposited in the soil through precipitation. These toxins will be subsequently be absorbed by plants, and possibly ingested by animals destined for the slaughterhouse. Some of these toxins such as the heavy metals do not biodegrade and are not eliminated, and will be concentrated as they travel up the food chain. The implications on the food supply is cause of major concern.

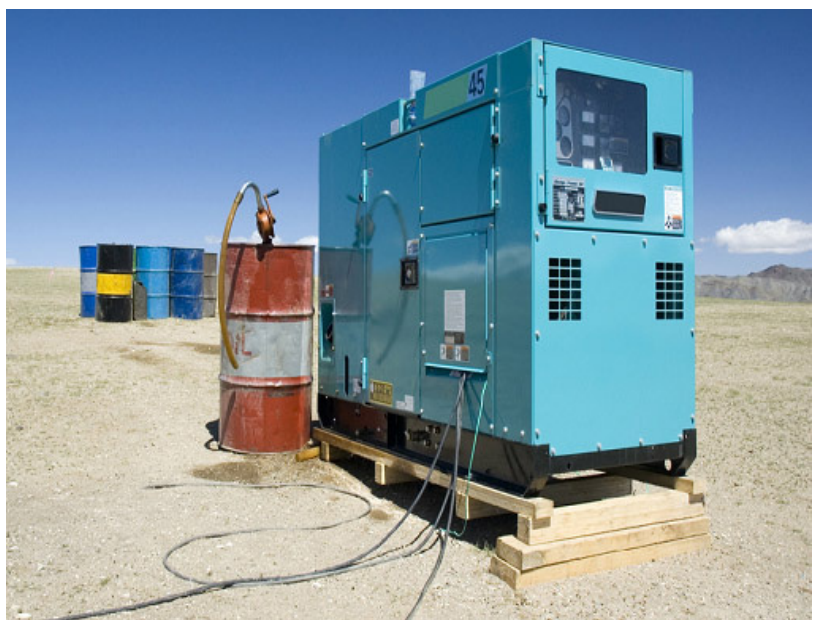

Figure $\mathbf{2}$ The standard diesel power generating system for a base station site [Hjorth et al. 2008]. 
The harmful effects on the water supply are similar, and of equal concern [Schneider, 2000].

\section{Cost of emissions}

World government (Canadian) is working rapidly to place a mandatory price on the emissions of greenhouse gases, including carbon dioxide $\left(\mathrm{CO}_{2}\right)$, which is produced by the combustion of diesel fuel. In the future, businesses will be required to reduce emissions or buy offset credits to offset $\mathrm{CO}_{2}$ emissions. There is currently a market for voluntary offsetting, with the price of emissions in the range of $\$ 6-\$ 11$ per tonne of $\mathrm{CO}_{2}$ emitted [Willson, 2009]. There is general agreement that the price of emissions must rise to at least $\$ 200 / t \mathrm{CO}_{2} \mathrm{e}$ [Willson, 2009] in order to have the desired effect of reducing the GHG emissions worldwide. The Canadian government is currently recommending a target price of $\$ 250$ /tonne $\mathrm{CO}_{2}$ by the year 2025. For a network containing current diesel-powered cell sites, the $\$ 200 / t$ price of emissions adds up to an additional operating expense of US $\$ 10669.86$ per year, per site [Willson, 2009].

\section{Model for calculating emission generation}

Many studies on the environmental impact of systems now use the National Renewable Energy Laboratory (NREL)'s, Hybrid Optimization Model for Electric Renewable (HOMER). It contains a number of energy component models and evaluates suitable technology options based on emissions. The HOMER software was used by [Kamel and Dahl, 2005; Khan and Iqbal, 2005; Lambert et al., 2006] to find optimum sizing and minimizing cost and emissions for power systems with specific load demands in standalone applications.

A simulation work on contaminating emissions $\left(\mathrm{CO}_{2}, \mathrm{NO}_{\mathrm{X}}\right.$ and particles) of a diesel generator was presented by [Wies et al., 2005] using Simulink and comparing the results with those obtained by means of HOMER [HOMER, 2012] software.

The equation for the calculation of generated emissions stated by [Lambert, 2009; Ani, 2012] is as follows:

$$
E_{a n n}=\frac{M_{\mathrm{CO}_{2}}+M_{C O}+M_{U H C}+M_{P_{M}}+M_{S_{2}}+M_{\mathrm{NO}_{x}}}{1000} \text { Eq. (1) }
$$

while the cost of emissions is calculated as follows:

$$
C_{\text {emissions }}=c_{\mathrm{CO}_{2}}+c_{\mathrm{CO}}+c_{U H C}+c_{P M}+c_{\mathrm{SO}_{2}}+c_{\mathrm{NO}_{x}} \text { Eq. (2) }
$$

Where:

$\mathrm{M}_{\mathrm{CO}_{2}} \quad$ : Annual emissions of $\mathrm{CO}_{2}\left(\mathrm{~kg} \mathrm{yr}^{-1}\right)$

$\mathrm{M}_{\mathrm{CO}} \quad$ : Annual emissions of $\mathrm{CO}\left(\mathrm{kg} \mathrm{yr}^{-1}\right)$

$\mathrm{M}_{\mathrm{UHC}}$ : Annual emissions of unburned hydrocarbons (UHC) $\left(\mathrm{kg} \mathrm{yr}^{-1}\right)$

$\mathrm{M}_{\mathrm{PM}} \quad$ : Annual emissions of particulate matter (PM) $\left(\mathrm{kg} \mathrm{yr}^{-1}\right)$

$\mathrm{M}_{\mathrm{SO}_{2}} \quad$ : Annual emissions of $\mathrm{SO}_{2}\left(\mathrm{~kg} \mathrm{yr}^{-1}\right)$

$\mathrm{M}_{\mathrm{SNX}} \quad$ : Annual emissions of $\mathrm{NO}_{\mathrm{X}}\left(\mathrm{kg} \mathrm{yr}^{-1}\right)$

$\mathrm{C}_{\mathrm{CO}_{2}}$ : Cost for emissions of $\mathrm{CO}_{2}\left(\$ \mathrm{t}^{-1}\right)$

$\mathrm{C}_{\mathrm{CO}}:$ : Cost for emissions of $\mathrm{CO}\left(\$ \mathrm{t}^{-1}\right)$

$\mathrm{C}_{\mathrm{UHC}}$ : Cost for emissions of unburned hydrocarbons (UHC) $\left(\$ \mathrm{t}^{-1}\right)$

$\mathrm{C}_{\mathrm{PM}}$ : Cost for emissions of particulate matter $(\mathrm{PM})\left(\$ \mathrm{t}^{-1}\right)$

$\mathrm{C}_{\mathrm{SO}_{2}} \quad$ : Cost for emissions of $\mathrm{SO}_{2}\left(\$ \mathrm{t}^{-1}\right)$

$\mathrm{C}_{\mathrm{NO}} \quad$ : Cost for emissions of $\mathrm{NO}_{\mathrm{X}}\left(\$ \mathrm{t}^{-1}\right)$

In this paper, the parameters useful for calculating emission generation are grouped into the following:

- Calculate the pollutant emission and;

- Calculate the cost of emission $\left(\$ \mathrm{t}^{-1}\right)$.

These two parameters summarize the factors proposed for evaluating the environmental impact of power generation for this study. The model is shown in Fig. 3.

This model was used to study the environmental impact of fossil fuel utilization for macro radio-type mobile phone base stations. 


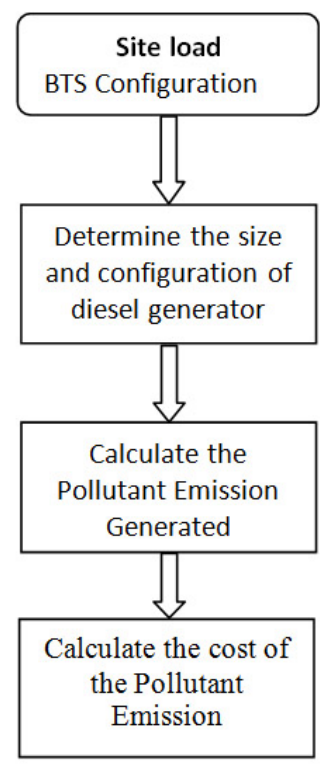

Figure 3 Model for calculating emission of power generation.

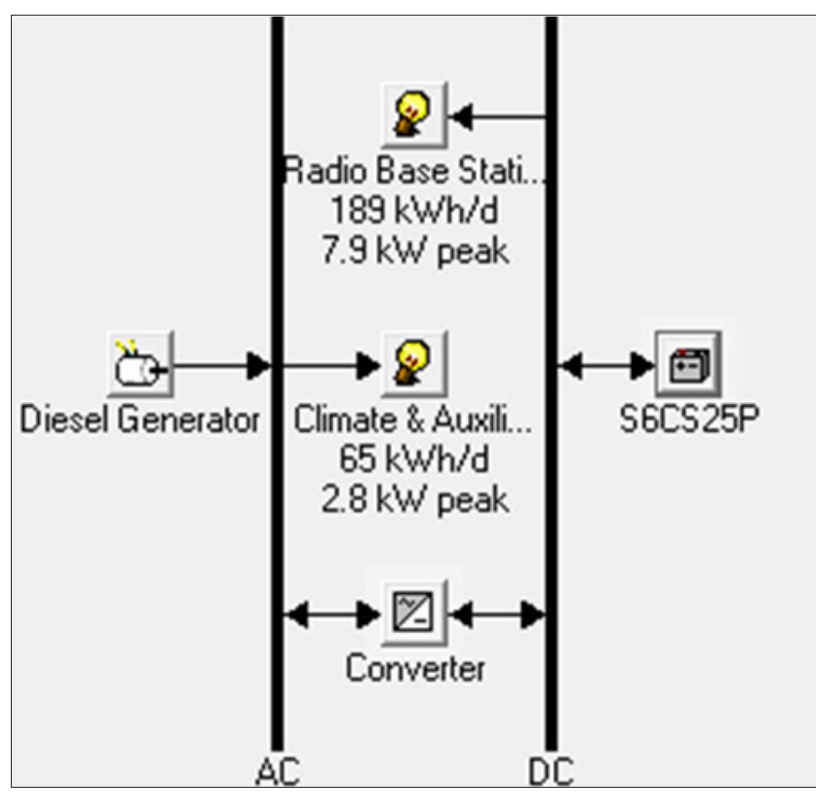

Figure 4 The diesel generator schematic diagram for a macro base station site.

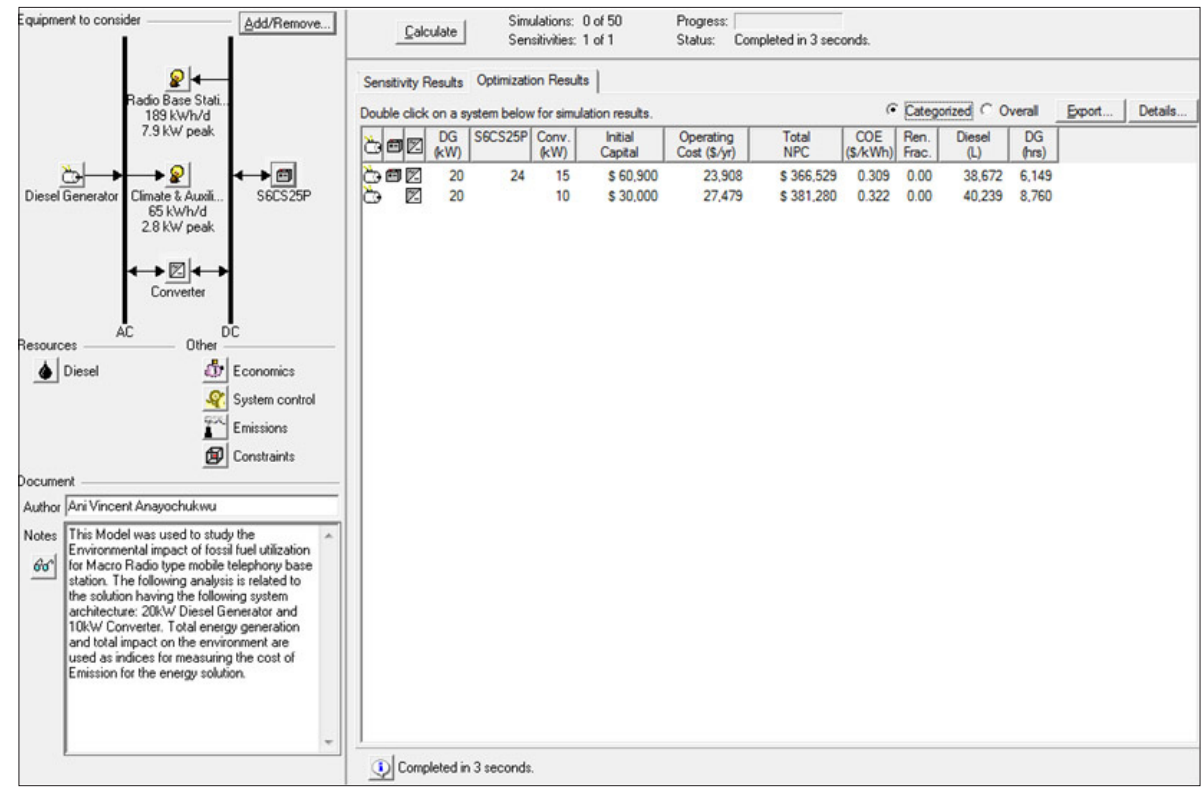

Figure $\mathbf{5}$ Overall optimization result output of HOMER solutions.

\section{Materials and methods}

To assess the environmental impact of powering base stations with diesel generators, the emissions generated were quantified in terms of pollution and the impact in terms of environmental cost. System sizing [Elhadidy and Shaahid, 2004; Nema et al. 2007(a), 2007(b)] was carried out using the HOMER-optimization and simulation software tool. For this study the power requirements for the macro radio GSM base station site are $10.7 \mathrm{~kW}$ continuous. The load demand is approximately $254 \mathrm{kWh} \mathrm{d}^{-1}$ and $10.7 \mathrm{~kW}$ peak. The system architecture has the following: $20 \mathrm{~kW}$ diesel generator, 24 Surrette 6CS25P battery cycle charging and $15 \mathrm{~kW}$ converter. The schematic diagram of the diesel generating system is shown in Fig. 4.

The overall optimization result output of HOMER solutions for the diesel/battery and diesel-only systems is shown in Fig. 5. 


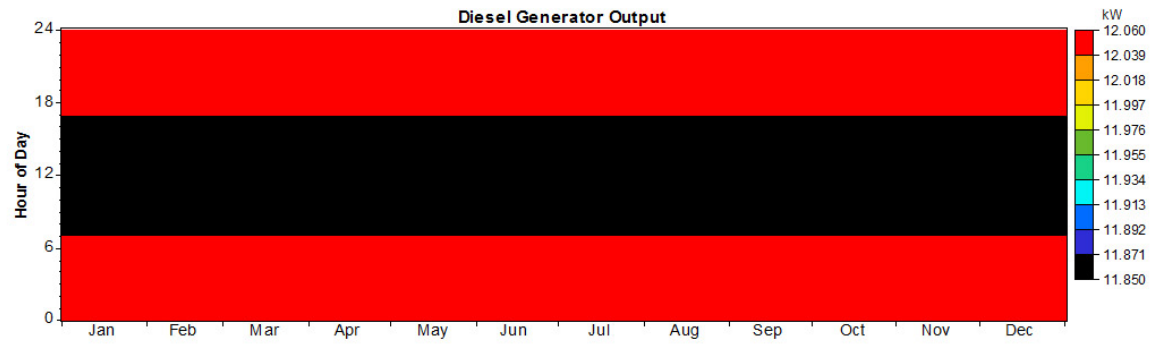

Figure 6 Output of diesel generator in diesel only system.

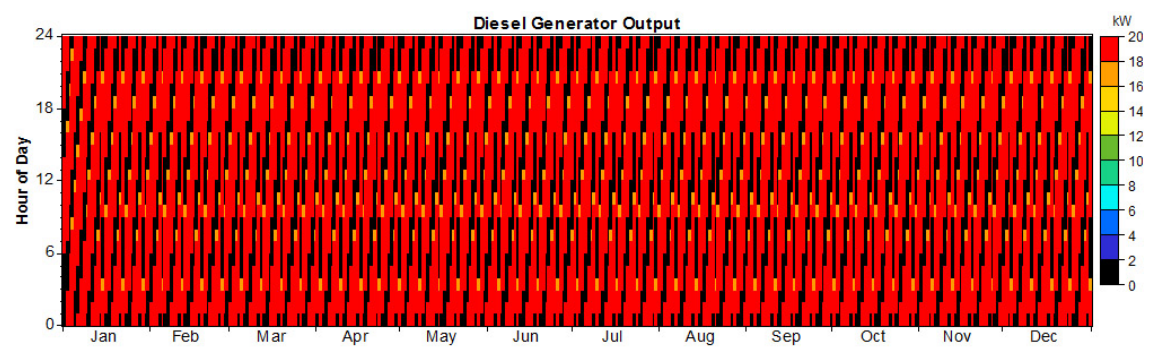

Figure7 Output of diesel generator in diesel/battery system.

\section{Results and discussion}

Simulations carried out by HOMER provided information concerning the environmental characteristics of the power system, such as $\mathrm{CO}_{2}$ emissions, and fuel consumption. The results obtained are presented in Tables 1 and 2. The detailed analysis obtained at the end of the simulation are described below as:

\section{Electricity production}

The diesel generator at this base station generates $115,327 \mathrm{kWh}$ of electricity per year which effectively powers the load demand of $92,711 \mathrm{kWh}$ per year with excess electricity of $22,616 \mathrm{~kW}$ per year; while in the diesel/battery system, it supplies $104,889 \mathrm{kWh} \mathrm{yr}^{-1}$ to the same load with little excess electricity of 12.178 $\mathrm{kW}$ per year.

In the diesel-only system, between 7:00 $h-17: 00$ $\mathrm{h}(7.00 \mathrm{am}-5.00 \mathrm{pm})$ the load is less $(10.45 \mathrm{~kW})$ and the output of the diesel generator is between 11.850 - 11.871 kW (black colour legend), while from 17:00 $\mathrm{h}-7: 00 \mathrm{~h}(5.00 \mathrm{pm}-7.00 \mathrm{am})$, the load increased $(10.65 \mathrm{~kW})$ and the output of the diesel generator is between $12.039-12.060 \mathrm{~kW}$ (red colour legend), as shown in Fig. 6.
The operation strategy of the diesel generator in a diesel/battery system works at nominal power, providing that the state of charge (SOC) of the batteries is within determined limits [Starting threshold (SDM) and Stopping threshold (SAR), in \% of the battery capacity]. When the output of the diesel generator is between $14-20 \mathrm{~kW}$ (yellow, orange and red colour legend), the diesel supplies to the load and at the same time charges the battery, while between $0-2$ (black colour legend), the battery supplies to the load as shown in Fig. 7.

\section{Environmental pollution}

The diesel-only system operates for $8,760 \mathrm{~h}^{\text {annum }}{ }^{-1}$ has a fuel consumption of 40,239 $\mathrm{L}$ annum $^{-1}$ and has its number of starts of once $\mathrm{yr}^{-1}$. It generates annually 105.962 tonnes of $\mathrm{CO}_{2}, 0.262$ tonnes of $\mathrm{CO}, 0.029$ tonnes of UHC, 0.0197 tonnes of PM, 0.213 tonnes of $\mathrm{SO}_{2}$, and 2.334 tonnes of $\mathrm{NO}_{\mathrm{X}}$ which are released into the atmosphere at the location under consideration as shown in Table 1 and 2. On the other hand, the diesel/battery system operates for $6,149 \mathrm{~h}^{\text {annum }}{ }^{-1}$ has a fuel consumption of 38,672 $\mathrm{L}$ annum $^{-1}$ and has a number of starts of 626 times $\mathrm{yr}^{-1}$. This system generates 101.835 tonnes of $\mathrm{CO}_{2}, 0.251$ tonnes of $\mathrm{CO}$, 
Table 1 Comparison of simulation of diesel/battery and diesel only.

\begin{tabular}{|lcccc|}
\hline \multirow{2}{*}{ Quantity } & \multicolumn{2}{c}{ Diesel/Battery } & \multicolumn{2}{c|}{ Diesel only } \\
& Value & Units & Value & Units \\
Hours of operation & 6,149 & $\mathrm{~h} \mathrm{yr}^{-1}$ & 8,760 & $\mathrm{~h} \mathrm{yr}^{-1}$ \\
Number of starts & 626 & starts yr-1 & 1 & starts yr \\
\hline Fuel consumption & 38,672 & $\mathrm{~L} \mathrm{yr}^{-1}$ & 40,239 & $\mathrm{~L} \mathrm{yr}^{-1}$ \\
\hline
\end{tabular}

Table 2 Comparison of simulation results of emissions from diesel/battery and diesel only.

\begin{tabular}{|c|c|c|c|c|}
\hline \multirow{3}{*}{ Pollutant } & \multicolumn{4}{|c|}{ Emissions } \\
\hline & \multicolumn{2}{|c|}{ Diesel/Battery } & \multicolumn{2}{|c|}{ Diesel only } \\
\hline & $\mathrm{kg} \mathrm{yr}^{-1}$ & ton $\mathrm{yr}^{-1}$ & $\mathrm{~kg} \mathrm{yr}^{-1}$ & ton $\mathrm{yr}^{-1}$ \\
\hline Carbon dioxide & 101,835 & 101.835 & 105,962 & 105.962 \\
\hline Carbon monoxide & 251 & 0.251 & 262 & 0.262 \\
\hline Unburned hydrocarbons & 27.8 & 0.0278 & 29 & 0.029 \\
\hline Particulate matter & 18.9 & 0.0189 & 19.7 & 0.0197 \\
\hline Sulfur dioxide & 205 & 0.205 & 213 & 0.213 \\
\hline Nitrogen oxides & 2,243 & 2.243 & 2,334 & 2.334 \\
\hline
\end{tabular}

0.0278 tonnes of UHC, 0.0189 tonnes of PM, 0.205 tonnes of $\mathrm{SO}_{2}$, and 2.243 tonnes of $\mathrm{NO}_{\mathrm{X}}$ as shown also in Table 1 and 2.

\section{Environmental cost}

The $\$ 200 \mathrm{t}^{-1}$ price of emission given by Canadian government was used in this study to value the emissions. All costs have been converted from USD (\$) into Naira $(\mathrm{N})$ as shown in Table 3 using the equivalent as 1 US Dollar (\$) equal to N162 of Nigerian currency [Exchange rate, accessed on 07/17/2012].

Using Eq. (2), the cost of emissions was calculated and tabulated. From Table 3, diesel/battery has total cost of emissions of $\$ 20,916.14$ (N 3,388,414.68) while the diesel only has a total cost of emissions of $\$ 21,763.94$ (N 3,525,758.28). Diesel/battery cost of emissions when compared with diesel only cost of emissions has a difference of $\$ 847.8$ (N 137,343.6) meaning that addition of a battery reduces the operational hour of the diesel generator, thereby reducing emissions and cost.

\section{Conclusion}

This study concludes that there is a strong case to quantify the environmental impact of using diesel in powering GSM base stations. Global greenhouse gasses (GHG) pollute the environment (air, water and soil) which will ultimately adversely affect the life of human beings. An indirect impact is the health and quality of life concerns that these GHGs generate.

From the simulation results, when the diesel operational hours are higher, $(8,760)$, the emissions generated are also higher compared to when the generator operates with battery for $6,149 \mathrm{~h}$. Thus, it can be concluded that the operational hours of diesel generators effect emissions generation. If the use of diesel-only generators persists by network operators in Nigeria, the pollutant emissions generated at each base station location could cause a health epidemic in the near future. 
Table 3 Comparison of cost of emissions from diesel/battery and diesel only.

\begin{tabular}{|c|c|c|c|c|c|c|}
\hline \multirow{3}{*}{ Pollutant } & \multicolumn{6}{|c|}{ Cost of Emissions } \\
\hline & \multicolumn{3}{|c|}{ Diesel/Battery } & \multicolumn{3}{|c|}{ Diesel only } \\
\hline & ton $\mathrm{yr}^{-1}$ & $\$ t^{-1}$ & $N t^{-1}$ & ton $\mathrm{yr}^{-1}$ & $\$ t^{-1}$ & $\mathbf{N} \mathbf{t}^{-1}=$ \\
\hline Carbon dioxide & 101.835 & 20,367 & $3,299,454$ & 105.962 & $21,192.4$ & $3,433,168.8$ \\
\hline Carbon monoxide & 0.251 & 50.2 & $8,132.4$ & 0.262 & 52.4 & $8,488.8$ \\
\hline Unburned hydrocarbons & 0.0278 & 5.56 & 900.72 & 0.029 & 5.8 & 939.6 \\
\hline Particulate matter & 0.0189 & 3.78 & 612.36 & 0.0197 & 3.94 & 638.28 \\
\hline Sulfur dioxide & 0.205 & 41 & 6642 & 0.213 & 42.6 & $6,901.2$ \\
\hline Nitrogen oxides & 2.243 & 448.6 & $72,673.2$ & 2.334 & 466.8 & $75,621.6$ \\
\hline Total & 104.5807 & $20,916.14$ & $3,388,414.68$ & 108.8197 & $21,763.94$ & $3,525,758.28$ \\
\hline
\end{tabular}

\section{Recommendation}

Although the essence of sitting base stations in a community is to give network coverage to the people, they should at the same time avoid polluting the environment and the habitat, by following the stipulated regulations for installing base stations. We therefore recommend that those in a position of authority take keen interest in enforcing the law that is guiding the location of these stations or mandate operators to use renewable energy technologies such as hybrid systems for powering the base stations, especially those that are close to schools and homes. Another crucial step is the development of an optimized energy atlas for appropriate locations of GSM base station sites in the country, both as a design guide for network operators and for the formulation of energy use policies by the national telecommunications regulatory authority (the NCC). One of these such policies could be the requirement that any network operator intending to site a base station in any location should first produce an optimized energy feasibility study of the location before an approval would be granted.

It is suggested that attention should be given to auditing of power generation at GSM base station sites to ensure compliance with emission levels.

In summary, we recommend the use of hybrid diesel power generation system to minimize GHG emissions in the telecommunications industry.

\section{References}

Adeofun, C.O.; Oyedepo, J.A. and Salami, O.A. (2009). Global system of mobile telecommunication (GSM) base stations as emission source in $\mathrm{Ni}$ geria: A gis-supported investigation. Proceedings of the 11th International Conference on Environmental Science and Technology Chania, Crete, Greece, 3 - 5 September 2009.

Ani, V.A. (2013). Optimal operational strategy for hybrid power generation at GSM base station site. International Journal of Energy Optimization and Engineering. Publisher IGI Global. (in press).

Ani, V.A. (2012). Energy Optimization at telecommunication base station Site. Ph.D thesis from Electronic Engineering, University of Nigeria Nsukka.

Ani, V.A. and Nzeako, A.N. (2012). Energy optimization at GSM base station located at rural areas. International Journal of Energy Optimization and Engineering. vol.1, no 3 .

California Air Resources Board. (2000). Risk reduction plan to reduce particulate matter emissions from diesel-fueled engines and vehicles. CARB Mobile Source Control Division.

Elhadidy, M.A. and Shaahid, S.M. (2004). Role of hybrid (wind + diesel) power systems in meeting commercial loads. Renewable Energy Review. vol 29, no 1, 109-118, http://dx.doi.org/10.1016/ S0960-1481(03)00067-3. 
Federal Ministry of Environment. (1991). Guidelines on the national air quality control and emission standards based on enactment of federal environmental protection agency' act. cap 131, s.17.

Ghosh, U. (2007). The role of black carbon in influencing availability of PAHs in sediments. Human and Ecological Risk Assessment: An International Journal. vol. 13, $\mathrm{n}^{\circ}$ 2, 276-285, DOI:10.1080/10807030701226731.

Hjorth, P.; Lövehagen, N.; Malmodin, J. and Westergren, K. (2008). Reducing CO2 emissions from mobile communications - BTS Power savings and Tower Tube. Ericsson Review.

Kamel, S. and Dahl, C. (2005). The economics of hybrid power systems for sustainable desert agriculture in Egypt. Energy. vol. 30, 1271-1281.

Khan, M.J. and Iqbal, M.T. (2005). Pre-feasibility study of stand-alone hybrid energy systems for applications in newfoundland. Renewable Energy. vol. 30, 835-854.

Lambert, T.; Gilman, P. and Lilienthal, P. (2006). Micropower system modeling with HOMER. National Renewable Energy Laboratory.

Nema, P.; Nema R.K. and Rangnekar, S. (2007a). Integrated design approach for stand alone PV-solar and wind hybrid energy system: for rural electrifications. International conference on advance energy systems (ICAER-2007) held at IIT Bombay.

Nema, P.; Nema R.K. and Rangnekar, S. (2007b). 'Sizing and methodology of pvsolar/wind hybrid energy systems' national conference of power electronics \& intelligent control held at Malaviya National Institute of technology Jaipur (rajasthan), India.

Schneider, C. (2000). The particulate-related health benefits of reducing power plant emissions. Bethesda MD. ABT Associates Inc.

Wies, R.W.; Johnson, R.A.; Agrawal, A.N. and Chubb, T.J. (2005). Simulink model for economic analy- sis and environmental impacts of a PV with diesel-battery system for remote villages. IEEE Trans Power Systems. vol. 20, nº 2, 692-700.

\section{Web Page}

Air Quality Technical Report. (2008). APPENDIX F: http://www.njtransit.com/pdf/Appendix $\% 20$ F\%20Air\%20Quality.pdf

Exchange rate for converting United States Dollar to Nigerian Naira: 1 USD $=161.49739$ NGN, Accessed on 07/17/2012, http://themoneyconverter. com/USD/NGN.aspx, http://themoneyconverter. com/USD/NGN.aspx\#exchange-rates

HOMER (The Hybrid Optimization Model for Electric Renewables). (2012). Available from: http:// www.nrel/gov/HOMER

GSMA. (2009). Environmental impact of mobile communications networks. Available at: http:// www.gsmworld.com/environment

Lambert, T. (2009). HOMER: The hybrid optimization model for electrical renewables. http://www. nrel.gov/international/tools/HOMER/homer. html

Madden, J. (2011). Renewable Energy World Article, "Wind and Solar to Answer the Call for Mobiles" Available at: www.renewablenergyworld.com

Pierre, G. (2006). Power system efficiency in wireless communication, Ericsson. Source: http://www. apec-conf.org/2006/APEC_2006_SP2_1.pdf

Roy, S. (2008). Energy logic for telecommunications. A white paper from the experts in business-critical continuity, Emerson Network Power. www. EmersonNetworkPower.com/EnergySystems

USEPA AIRS database. (2008). www.epa.gov/air/ data.com.

Willson John. (2009). Energy \& Emissions at Cellular Base Stations. WireIE Holdings International Inc, Canada. pg.3. www.wireie.com 
